\title{
鉄一銅圧粉体の寸法变化に及ぼす銅添加方法の影響
}

\author{
黒木 英 憲漓，藤 沢 伸 也祙 \\ 莒1 広島大学工学部第一類, 干724 東広島市鏡山1丁目.

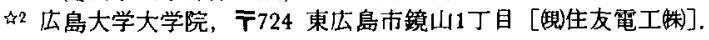

\section{The Effect of Techniques for Copper Addition on the Dimensional Changes of Iron-Copper Powder Compacts}

\author{
Hidenori Kuroki ${ }^{i 2}$ and Shinya Fujisawa ${ }^{i 2}$ \\ \&1 Dep. Mech. Eng., Fac. Eng., Hiroshima University, 1-4-1 Kagamiyama Higashi-hiroshima 724.

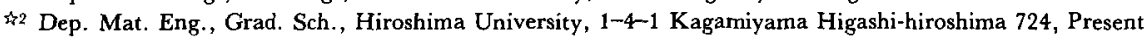 \\ address: Sumitomo Electric Industries, Ltd.
}

Received November 8, 1990

\begin{abstract}
The dimensional changes during compacting and sintering were measured. Less than 5 mass $\%$ of copper was added to the Hoeganaes NC100.24 iron powder, as electrolytic powder, or as a coating by the substitutionprecipitation process, or as 20 mass $\% \mathrm{Cu}$ Distaloy powder. They were further mixed with 0.7 mass $\%$ of zinc stearate and pressed under $490 \mathrm{MPa}$ to form compacts $10 \mathrm{~mm}$ in diameter and $10 \mathrm{~mm}$ in height. The compacts were dewaxed by heating at the rate of $50 \mathrm{~K} / \mathrm{min}$ up to $873 \mathrm{~K}$, being held for $30 \mathrm{~min}$, and sintered successively by heating at the rate of $30 \mathrm{~K} / \mathrm{min}$ up to $1398 \mathrm{~K}$ and being held for $30 \mathrm{~min}$ in dissociated ammonia.

No effects of techniques for copper addition were found on the spring-back during compacting. The dimensional changes obtained after sintering generally indicated a tendency to expansion with an increase in the copper content. The coated powder had an almost constant difference between the dimensional changes in the compacting and in the lateral directions, though the mixed powder had an increasing tendency to expansion with an increase in the copper content in the compacting direction.
\end{abstract}

\section{I 緒 言}

機峨部品用鉄一銅合金焼結材料の製造には，一般に鉄 粉に銅粉を少量混合して加圧成形後, 銅の融点以上に加 熱する．この方法では銅液相の存在が鉄粒子の焼結や再 配龺を促進するので，焼結体の維密化が進み，さらに合 金化による強化が起こるなどの利点がある1)。しかし， 鉄粉之銅粉は成形に先立つ取り扱いや搬送中に分離しや すく, 製品の組成や寸法の均一性を損なら22ので，個々 の純鉄粒子に純銅を付着させた複合粉として抬散結合粉 と被覆粉の利用が考えられている。まず払散結合粉によ る鉄一銅絖結体では混合粉を用いたるのより寸法公差が
小さく，機械的性質も衝撃，引張り，疲労特性がよいと 報告されている3 的性質が改善され，特心銅膨張が抑制されるといら報告 がある ${ }^{6,7)}$.

この銅膨張現象は大きな課題として従来も注目されて いる ${ }^{8 \sim 11)}$ が，焼結に先行する成形過程を研究した例は 少ない、しかし，電解鉄粉において，焼結初期段階の寸 法変化量が成形段階の寸法変化量とほぼ比例し，しか心 それを越えないなど、焼結挙動に対して成形挙動が直接 影響する例も認められている ${ }^{12)}$ 。従って，銅の影響を検 討する場合も，まず成形挙動を知ることによって焼結時 の寸法変化の様々な面を総合的に把握すれば，製品の寸 
法精度の改善のみならず焼結機構の解明にも大きく寄与 するであろう。

そこで本資料では, 混合粉, 被覆粉, 拡散結合粉につ いて銅の含有率を変え, 成形挙動と寸法変化挙動を焼結 体の組織の变化に関連付けて検討した結果を報告する。

\section{II 実 験 方 法}

\section{II-1 原料粉末}

母材鉄粉としてすべてに還元鉄粉（へガネス社製 NC100・24）を用いた。本実験では，これを基に硫酸銅 水溶液から鉄粉表面に銅を所定の mass\% たけ置換析出 させて還元したものを純被覆粉と呼び, 電解銅粉 (福田 金属䇴粉社製 CE-5) を鉄粉に混合して各組成にしたも のを混合粉と呼ぶ.また，混合粉で用いた電解銅粉の代 わりにへガネス社の Distaloy 粉 $(\mathrm{Fe}-20.00$ mass $\% \mathrm{Cu})$ を 鉄粉に混ぜて各組成にしたものを拡散結合粉と呼び, 同 様に $\mathrm{Fe}-20.78$ mass\% $\mathrm{Cu}$ 被覆粉を鉄粉に混ぜて各組成に したものを被覆混合粉と呼ぶ.

銅含有率の目標値は, 現在工業的によく用いられてい

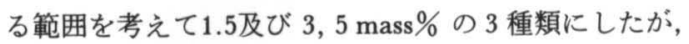
実際の被覆量は1.60及び3.06, 4.87 mass\% であったの で, 他の添加方法でもその 3 つの含有率に揃えた. なお, 一部の実験には 4.79 mass\% $\mathrm{Cu}$ の被覆粉も使用した.

粉末の特性を Table 1 に示し, Fig. 1 には複合粉の内,
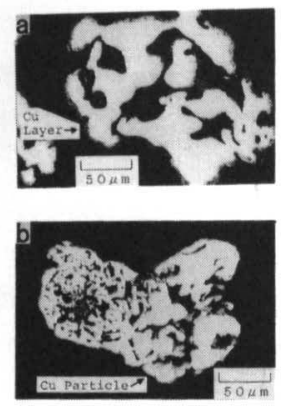

Fig. 1 Sections of particles of typical composite powders.

(a) $\mathrm{Fe}-20.78$ mass $\% \mathrm{Cu}$ coated powder

(b) $\mathrm{Fe}-20.00$ mass $\% \mathrm{Cu}$ bonded powder
$\mathrm{Fe}-20.78$ mass $\% \mathrm{Cu}$ の被覆粉と $\mathrm{Fe}-20.00$ mass $\% \mathrm{Cu}$ の払 散結合粉の断面写真を示す.

II-2 圧粉体

上記の粉末に潤滑剂としてステアリン酸亜鉛（堺化学 社製）を 0.7 mass\% 加え, V 型混合機で $30 \mathrm{~min}$ 混合し, $490 \mathrm{MPa}$ の両押しで $\phi 10 \times \mathrm{h} 10 \mathrm{~mm}$ の圧粉体を成形し た．成形の際に既報の手順 ${ }^{13)} に よ り$ 除荷及び型抜きの スプリングパック量を測定し, それらを型抜き後の寸法 と比較して除荷及び型抜きのスプリングハック率を求 め, 両者を加えて成形加圧方向の全スプリングハッッ率 とした。 また加圧力に直角の方向については型抜きスプ リングハッック率を求めた.

\section{II-3 焼結体}

脱ろら及び焼結を同一の横型炉で連続的に行い, 雾囲 気として流量約 $200 \mathrm{~L} / \mathrm{hr}$ の分解アンモニアガスを通じ た. 温度サイクルは実際に工業的に用いられている例に 合わせ, 炉をまず $873 \mathrm{~K}$ まで $50 \mathrm{~K} / \mathrm{min} て ゙$ 昇温し, そこ で $30 \mathrm{~min}$ 脱ろうし, 次に $1398 \mathrm{~K}$ まで $30 \mathrm{~K} / \mathrm{min}$ で昇温 し, そこで $30 \mathrm{~min}$ 焼結した。焼結後は $873 \mathrm{~K}$ 以下まで 最大約 $30 \mathrm{~K} / \mathrm{min}$ で泠却し, その後試料を水冷ジャケッ ト部に移して速やかに冷却した.

この脱ろら・焼結の前後で成形加圧方向とそれに直角 の方向の寸法を測定し, 型抜き後の圧粉体を基準とする 寸法変化率を求めた ${ }^{13)}$.

なお, 組織観察試料については昇温や焼結の途中で加 熱を打ち切って冷却した.

\section{III 結果}

III-1 スプリングパック

Fig. 2 (a)〜 (d) によれば銅含有率の変化に対して各ス プリングハッック率はほぼ一定であり, また添加方法によ ってもその值はほとんど変わらない、すなわち成形加圧 方向の型抜きスプリングハッック率は約 $0.3 \%$, 同じく除 荷スプリングパック率は約 $0.8 \%$ で，両者を合計した成 形加圧方向の全スプリングハック率は約 $1.1 \%$ となる. 他方, 加圧力に直角の方向の型抜きスプリングハッック率 は約 $0.2 \%$ である.

Table 1 Powder characteristics.

\begin{tabular}{c|c|c|c|c|c|c|c|c}
\hline $\begin{array}{c}\text { Powder and } \\
\text { Cu in mass\% }\end{array}$ & $\begin{array}{c}\mathrm{NC100.24} \\
-0 \% \mathrm{Cu}\end{array}$ & $\begin{array}{c}\mathrm{NC} 100 \% 24 \\
-1.60 \% \mathrm{Cu}\end{array}$ & $\begin{array}{c}\mathrm{NC} 100.24 \\
-3.06 \% \mathrm{Cu}\end{array}$ & $\begin{array}{c}\mathrm{NC} 100.24 \\
-4.79 \% \mathrm{Cu}\end{array}$ & $\begin{array}{c}\mathrm{NC} 100.24 \\
-4.87 \% \mathrm{Cu}\end{array}$ & $\begin{array}{c}\mathrm{NC100.24} \\
-20.78 \% \mathrm{Cu}\end{array}$ & $\begin{array}{c}\text { Distaloy } \\
-20.00 \% \mathrm{Cu}\end{array}$ & $\begin{array}{c}\mathrm{CE}-5 \\
-100 \% \mathrm{Cu}\end{array}$ \\
\hline $\begin{array}{c}\text { Apparent } \\
\text { density }\end{array}$ & $\begin{array}{c}\left(\mathrm{Mg} / \mathrm{m}^{3}\right) \\
2.45\end{array}$ & $\begin{array}{c}\left(\mathrm{Mg} / \mathrm{m}^{3}\right) \\
2.46\end{array}$ & $\begin{array}{c}\left(\mathrm{Mg} / \mathrm{m}^{3}\right) \\
2.37\end{array}$ & $\begin{array}{c}\left(\mathrm{Mg} / \mathrm{m}^{3}\right) \\
2.03\end{array}$ & $\begin{array}{c}\left(\mathrm{Mg} / \mathrm{m}^{3}\right) \\
2.30\end{array}$ & $\begin{array}{c}\left(\mathrm{Mg} / \mathrm{m}^{3}\right) \\
\left(\mathrm{Mg} / \mathrm{m}^{3}\right)\end{array}$ & $\begin{array}{c}\left(\mathrm{Mg} / \mathrm{m}^{3}\right) \\
2.83\end{array}$ \\
\hline Size distribution & $(\mathrm{mass} \%)$ & $(\mathrm{mass} \%)$ & $(\mathrm{mass} \%)$ & $($ mass\%) & $(\mathrm{mass} \%)$ & $(\mathrm{mass} \%)$ & $(\mathrm{mass} \%)$ & $(\mathrm{mass} \%)$ \\
$+149 \mu \mathrm{m}$ & 3.7 & 5.2 & 4.9 & 11.5 & 5.2 & - & 23.6 & 9.1 \\
$-149+105 \mu \mathrm{m}$ & 29.5 & 24.2 & 24.6 & 30.9 & 25.4 & - & 53.6 & 44.3 \\
$-105+74 \mu \mathrm{m}$ & 27.6 & 27.0 & 29.8 & 31.3 & 28.4 & - & 15.3 & 25.1 \\
$-74+62 \mu \mathrm{m}$ & 5.5 & 10.9 & 11.7 & 11.5 & 11.4 & - & 2.6 & 7.7 \\
$-62+44 \mu \mathrm{m}$ & 18.7 & 11.9 & 12.4 & 8.9 & 11.8 & - & 3.7 & 7.6 \\
$-44 \mu \mathrm{m}$ & 15.0 & 20.8 & 16.6 & 5.9 & 17.8 & - & 1.2 & 6.2 \\
\hline
\end{tabular}




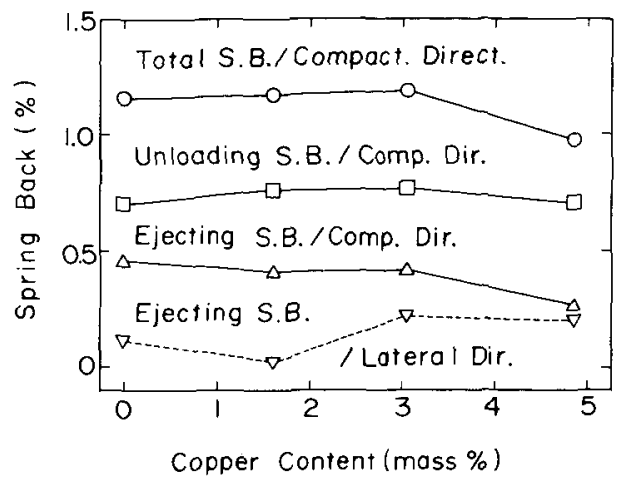

(a) coated powder

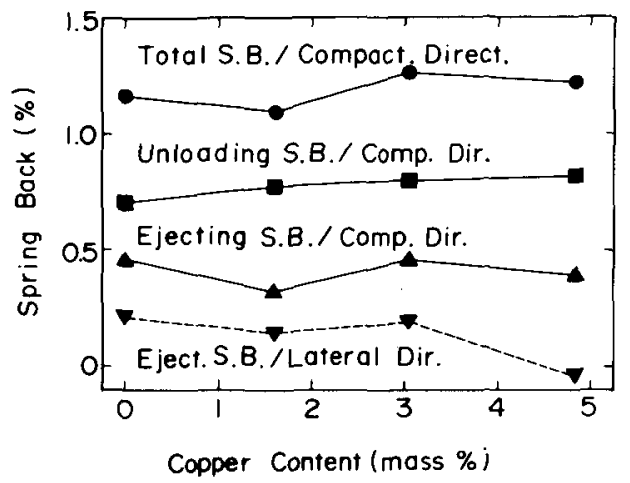

(b) mixed powder

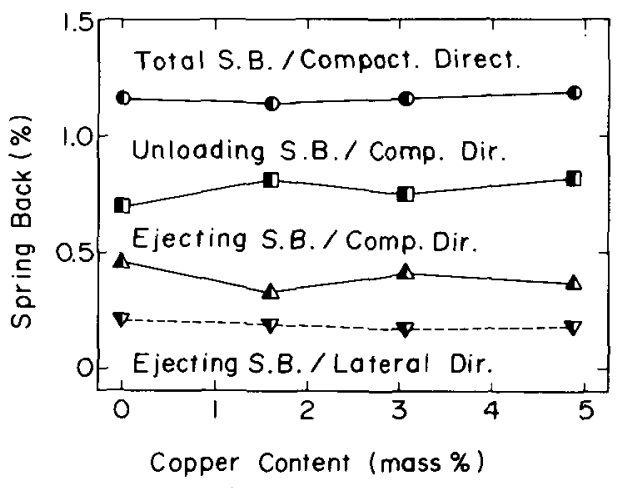

(c) bonded powder

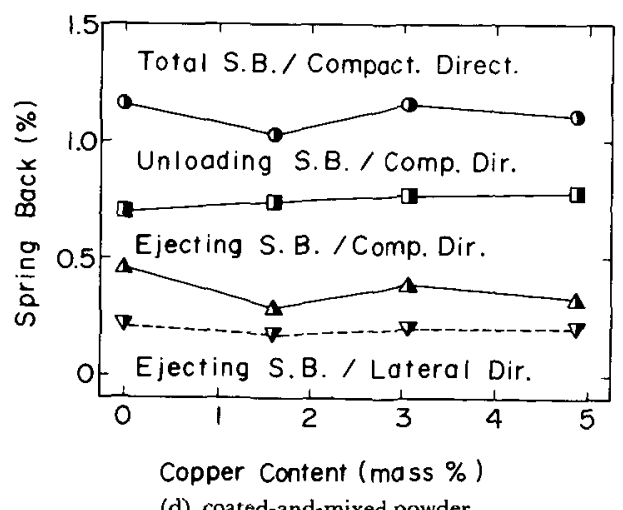

(d) coated-and-mixed powder

Fig. 2 Copper content vs spring-back of different types of powders in compacting and lateral directions.

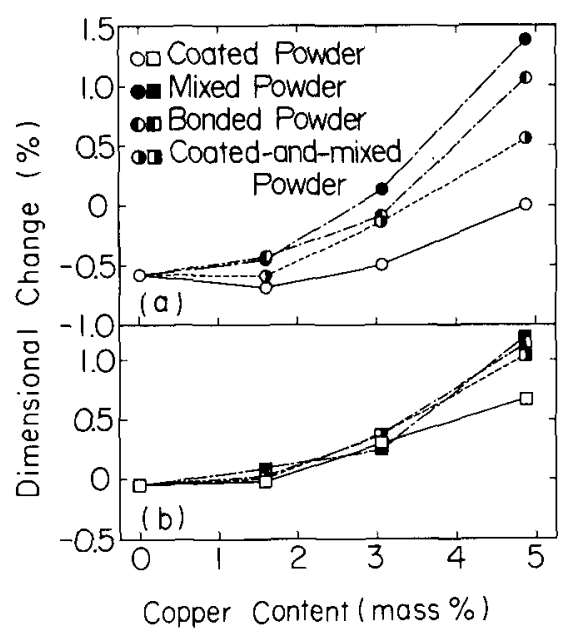

Fig. 3 Copper content vs dimensional change during dewaxing and sintering of different types of powders in compacting and lateral directions.

(a) compacting direction

(b) lateral direction

\section{III-2 焼結寸法变化}

\section{(a) 銅含有率の影響}

鉄一銅圧粉体の焼結に伴う銅䁗張現象の大きさが成形 加冉方向とその直角方向とで異なるかどらかは，これま で調べられていない，両方向について焼結後の寸法変化 率を求めた Fig. 3 (a)，(b)に上れば，各粉末上も銅含有 率の増加伴って全般的汇膨張傾向を示しているが， 1.60 mass\% $\%$ u 被覆粉の加圧方向に限り，一度純鉄より 収縮している．また純被覆粉の場合，常に加圧直角方向 の方が約 $0.6 \sim 0.7 \%$ 程度大であるのに対し，搌合粉の場 合は銅含有率の增加に伴って加圧方向の膨張傾向が大き くなり，その結果，方向による差が小さくなって 4.87 mass\% $\mathrm{Cu}$ では逆転している，さらに拡散結合粉と被覆 混合粉では，加圧直角方向が混合粉と同傾向をたどり， 加圧方向は純被覆粉と混合粉の中間の傾向をとってい る。

\section{(b) 顕微鏡組織}

前揭 Fig. 3 と同様に焼結した 4.87 mass\%Cu 混合粉と 4.79 mass\% $\mathrm{Cu}$ 被覆粉の試料について，冷却後の断面を 研磨・腐食して組織を観察した，Fig. 4 は混合粉につい て (a) 銅溶融直後, (b) 銅溶融後約 $3 \mathrm{~min}$, (c) 銅溶融後約 $6 \mathrm{~min}$, (d) 定温保持後の各時点の組織を示す，被覆粉に ついては Fig. 5 K, (a) 銅溶融前約 $3 \mathrm{~min}$, (b) 銅融点付近, (c) 銅溶融後約 $3 \mathrm{~min},(\mathrm{~d})$ 定温保持後の各組織を示す. まず混合粉では，銅の溶融直後 (Fig. 4(a)) 亿周りの鉄 粒子を濡らして銅中に気孔が生しる。銅溶融後的 $3 \cdot \mathrm{min}$ (同図 (b)）には銅液相が鉄粒子境界户鉄結晶粒界一浸透 し，そこからわずかに鉄粒子中拡散している，鉰溶融 後約 $6 \min ($ 同図 (c)) では拡散が更に進み, 境界や粒界 

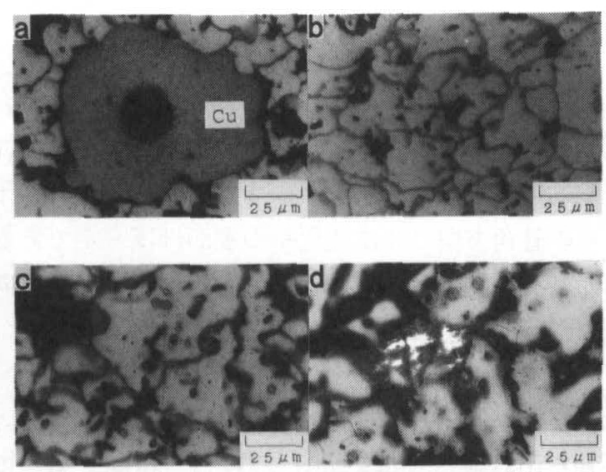

Fig. 4 Microstructures of $\mathrm{Fe}-4.87$ mass\% $\% \mathrm{Cu}$ mixed powder compacts.

(a) cooled immediately after the melting of copper

(b) cooled $3 \mathrm{~min}$ after the melting of copper

(c) cooled $6 \mathrm{~min}$ after the melting of copper

(d) cooled $30 \mathrm{~min}$ after the melting of copper
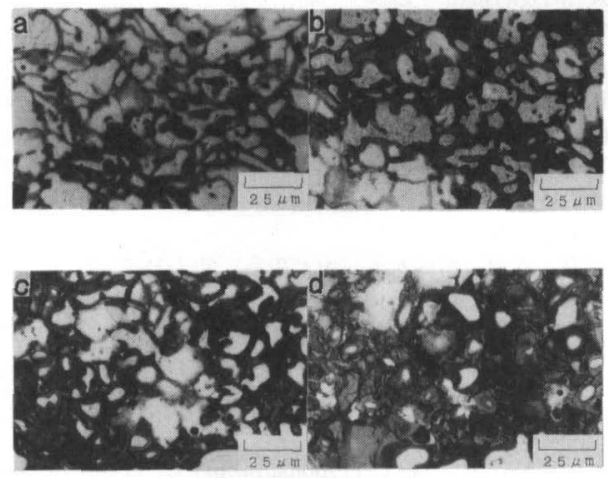

Fig. 5 Microstructures of $\mathrm{Fe}-4.79$ mass $\% \mathrm{Cu}$ coated powder compacts.

(a) cooled $3 \mathrm{~min}$ before the melting of copper

(b) cooled near the melting of copper

(c) cooled $3 \mathrm{~min}$ after the melting of copper

(d) cooled $30 \mathrm{~min}$ after the melting of copper

へ浸透した銅の膜は消える。定温保持後 (同図 $(d))$ には 銅の膜は見兄ず拡散は一層進行しているが，ほぼ純鉄の ままと見受けられる部分も存在し，完全には合金化して いない。また, 小さな気孔に流机込んで鉄結晶内に拡散 しないまま残っている銅 (正確には $\mathrm{Cu}$ 側固溶体) も点々 と認められる.

次に被覆粉では，銅が溶融前（Fig. 5 (a)) に既にかな り鉄の粒子表面や結晶粒界に拡散している. 銅の溶融後 (同図 (c)) にはそれが一層促進され，混合粉の場合に比 べて拡散の進行が速いよらである. 定温保持後 (同図 (d)) では，混合粉に見られた $\mathrm{Cu}$ 側固溶体は認められな い.

$$
\mathbf{N} \text { 考察 }
$$

\section{N-1 成形挙動}

加压方向のスプリンク゚パック機構として，まず除荷の
段階では, 個々の粉末粒子の弾性的回復（膨張）とそれ による粒子間結合の緩み，ならびに金型空間寸法の回復 （収縮）で絞られることによる加圧方向への弾性膨張が 考えられている. 更に次の型抜き段階では，微小層状割 れによる粉末粒子間の結合の緩みが加わるようである2゙. この観点に立てば，粒子表面に軟質の純銅層を持つ純被 覆粉では，銅含有率が増加するに伴い粉末粒子間の結合 が強くなって緩みが小さくなり、スプリングバック率が 低下すると予想される，しかし，実際の結果では銅の添 加方法や含有率の影響がはっきりとは認められなかった (Fig. 2 (a)). 従って, 銅被覆層の冷間接着効果がそれ枉 と゚大きくなかったか, あるいはその層の微小塑性変形に よって割れを伴わないスブリングパックが増大している 可能性がある.

要するに, 成形挙動には銅の添加方法は大きく影響せ ず，母体鉄粉の特性が主に作用するよらである.

\section{$\mathrm{N}-2$ 焼結挙動}

上に述べたように混合粉と被覆粉の寸法変化挙動の差 は, 粒子境界や結晶粒界に出現した液層の挙動の差に対 応している. 従って, 銅の量や添加方法によって焼結寸 法変化率が異なる最大の原因は, 銅溶融時に新たにそれ らの境界や粒界に入り込む液相量の差であると考えられ る.すなわち, 圧粉体中での銅と鉄の分布及び接触状況 を図解すれぱFig. 6 のようになるであろ5。これに基づ いて接触面積の小さいものから順に並べれば, (a) 粗大 な銅粉 (Table 1 参照) を混合している混合粉，(b) 細かい 銅粉が斑点状に付着した鉄粉 (Fig. 1 (b)) を混合した払散 結合粉, (c) 銅が鉄粒子を厚くしかも完全に被覆してい る鉄粉 (Fig. 1 (a)) を混合した被覆混合粉, (d) 個々の粒

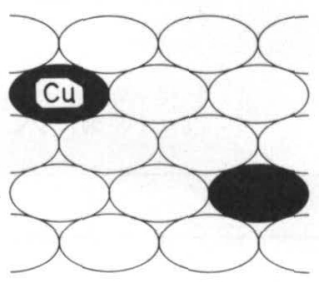

(a) mixed powder

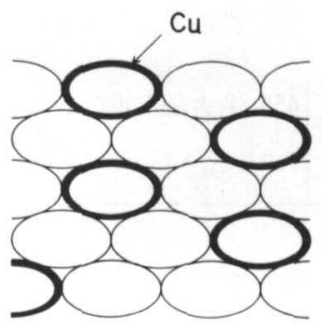

(c) coated-and-mixed powder

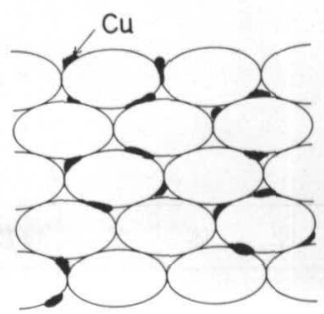

(b) bonded powder

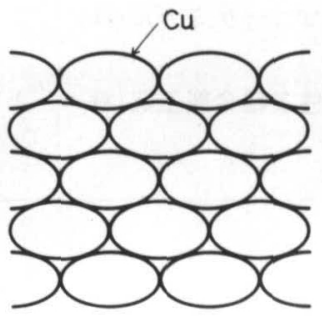

(d) coated powder
Fig. 6 Illustrations of $\mathrm{Fe} / \mathrm{Cu}$ contacts in compacts of different types of powders. 
子が薄い、銅で覆われた純被覆粉である，接触面積が小さ い方が溶融前に鉄粒子中に抁散する銅の量は少なく，銅 溶融時に新たに粒子境界や結晶粒界に浸透する液相量は 多くなると推測される. 従って Fig. 3 において混合粉で は銅含有率の増加に伴って液相量が增し, それが境界や 粒界に入り込むために急激に膨脹すると理解することが できる．逆に純被覆粉では銅含有率が增しても液相量が あまり增加しないし，境界や粒界一の新たな浸透も起き ないから，膨張傾向が強くならないのであろう。払散結 合粉と被覆混合粉では液相量が上記 2 者の中間であるた めに，両者の間の傾向をとると思われる.

銅含有率增加に伴 5寸法変化率の增加傾向 (Fig. 3) が，特に混合粉で異方性であり加圧方向に大きいのに対 し，純被覆粉でほぼ等方的であることも，やはり銅の溶 融後に新たに境界や粒界に浸透する液相量から説明され る.一般に一軸加圧圧粉体では粒子の変形に起因して， 単位長さ当たりの粒子境界や結晶粒界の数，いわば境界 密度は，加圧方向の方が直角方向よりも大きいはずであ る. 従って混合粉では銅含有率の增加に伴って浸透する 液相量も増加し，他方被覆粉では新たな浸透が汪とんど 起こらないと考えられる.むしろ純被覆粉の寸法変化の 異方性は鉄や $\mathrm{Fe}-\mathrm{Cu}$ 固溶体の固相焼結传左右され，そ のために純鉄の場合2) と類似の異方性を示すのである 5 .

\section{$\mathrm{V}$ 結 言}

約 5 mass\% までの範囲で銅含有率が異なる鉄一銅圧粉 体を混合粉と被覆粉, 払散結合粉から作製し, 成形及び 焼結中の寸法变化挙動に及汪す銅添加方法の影響を検討
した。

成形時のスプリンダバックに対しては銅添加方法の影 響は見られなかった。

焼結後に測定した寸法変化率は銅含有率の增加に伴っ て全般的に膨張傾向であった。 また純被覆粉では加圧方 向とその直角方向の寸法変化率の差がほぼ一定であるの に対し，混合粉では銅含有率の増加に伴って加圧方向の 膨張傾向が著しくなった。

本資料を発表するに当たり，卒業研究として実験に男 力された山口浩二（現才ムロン(株)），伊藤 勢（現才 ムロン(株))，WONG KIM KWEE（現日立粉末治金 (株)）の諸氏に厚く御礼申し上げます。

\section{文献}

1) R. M. German : Liquid Phase Sintering, Plenum Press, New York (1985), 1.

2) 黑木：塑性と加工, 27 (1986), 1110.

3) L. E. Svensson and U. Engstrom : Powder Metallurgy, 22 (1979), 165.

4) U. Engstrom : Metal Powder Report, 42 (1987), 22.

5) W. B. James and R. C. O'Brien : Metal Powder Report, 42 (1987), 250.

6) 小原，立沢：粉体および粉末治金，30 (1983),190.

7）小原，立沢：粉体および粉末治金，33(1986),139.

8）渡辺，川口：鋳研報告, 27 (1973),66.

9）小原，立沢：粉体扎上び粉末治金，21 (1974),91.

10) V. B. Phadke and B. L. Davies : Int. J. Powder Metall. and Powder Technol., 13 (1977), 253.

11) W. A. Kaysser, W. J. Huppmann and G. Petzow : Powder Metallurgy, 23 (1980), 86.

12）黑木：粉体および粉末治金, 33 (1986), 187.

13）黑木，中村，片島：粉体および粉末冶金，35 (1988),469.

新入特別会員 (平成 3 年 6 月 6 日現在)

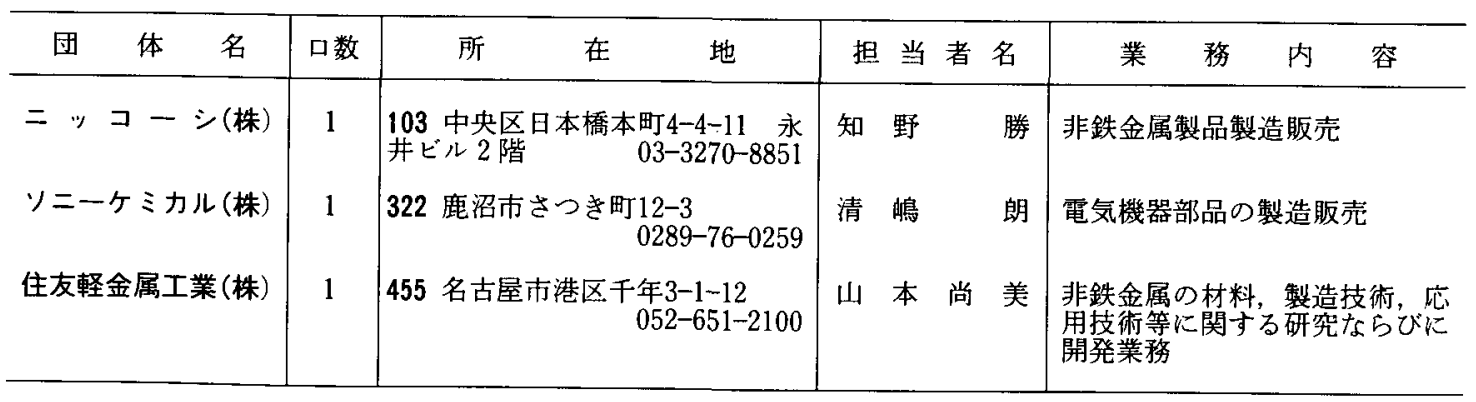

